\title{
IRON A FACTOR IN THE WORLD'S PROGRESS.*
}

\author{
BY \\ JOHN BIRKINBINE, \\ Consulting Engineer. \\ Member of the Institute.
}

THE European war, while drawing heavily upon the resources affecting industries of contending nations, also seriously influences conditions in countries throughout the world not engaged in hostilities, threatening lasting effect and possible future changes in many phases of development. For this reason a discussion is offered of the relative positions of the leading countries which produce pig iron or supply the requisite raw materials for its manufacture, and to indicate past as well as present conditions a period of at least four decades has been chosen as covering practically the era of greatest industrial growth.

Prognostications as to future conditions are not attempted, but analyses of the data presented may suggest possibilities for nations now prominent or others wherein the development or utilization of the above commodities is less pronounced, while similar studies of other industrial specialties may indicate even greater changes.

Iron ore and coal hold leading rank among mineral resources whose development has been and is coincident with the world's progress, for countries possessing these abundantly, or utilizing them liberally, are the dominant nations.

The United States produces more coal, more iron ore, and more pig iron than any other nation, and her strongest competitors are the European countries now at war, for they are each an important factor in the supply of some or all of the above, and, together with the United States, are depended upon for

85 per cent. of the iron ore,

96 per cent. of the pig iron supply of the world,

89 per cent. of the coal.

They are also the most active producers of varied forms of iron and steel manufactures, a large proportion of their inhabi-

* Communicated by the Author. 
tants being skilled and efficient in mine, furnace and mill work.

A disturbance as momentous as that produced by the European conflict is far-reaching in its effect upon industrial progress, and its influence may be expected to continue long after peace is declared: for animosities do not cease with the suspension of active hostilities.

Consideration of iron as a factor in the world's progress necessarily is dependent on statistics, but, to relieve the discussion of voluminous tables, charts are presented on which are traced the conditions prevailing since I870 in iron ore, coal, and pig iron productions of important nations. The quantities recorded are in long tons (2240 pounds), except for countries using the metric system, where the amounts are given in metric tons (2204 pounds).

Iron Ore.

Plate A illustrates the annual production of iron ores in the countries which have been or are prominent in supplying this mineral. The ordinates indicate in tons (the space between two longitudinal lines representing five million tons) the outputs of each country, designated by a particular form of line; the abscissæ show the years. By tracing the "curve" for any country, its production in a given year is found, or its contemporaneous position with other iron ore producing nations is demonstrated. Thus Plate A shows that Great Britain was the largest contributor of iron ore until 1889 , when the United States took first place, and since I895 Germany has exceeded the output of Great Britain. The contemporaneous contributions of the three nations were practically equal in the years 1893 and I894, subsequent to which time the advance of Germany and of the United States has been more pronounced than that of Great Britain. In late years the iron ore output of France has materially advanced. It will be noted that the maximum annual productions of iron ore were, for the United States I9I3, Great Britain 1882, Germany and Luxemburg I9r3, ${ }^{1}$ France I9r2, Spain 1907, Russia I9I I (?), Sweden I9I3, Austria-Hungary I9II (?). ${ }^{2}$

${ }^{1}$ The statistics of Luxemburg, which supplies liberal quantities of iron ore and coal, have been officially combined with those of Germany.

(?) intimates that no authentic records are available subsequent to the date mentioned. 
In addition to the countries designated in the graphic representation, the islands of Cuba and New foundland are each supply-

Plate A.

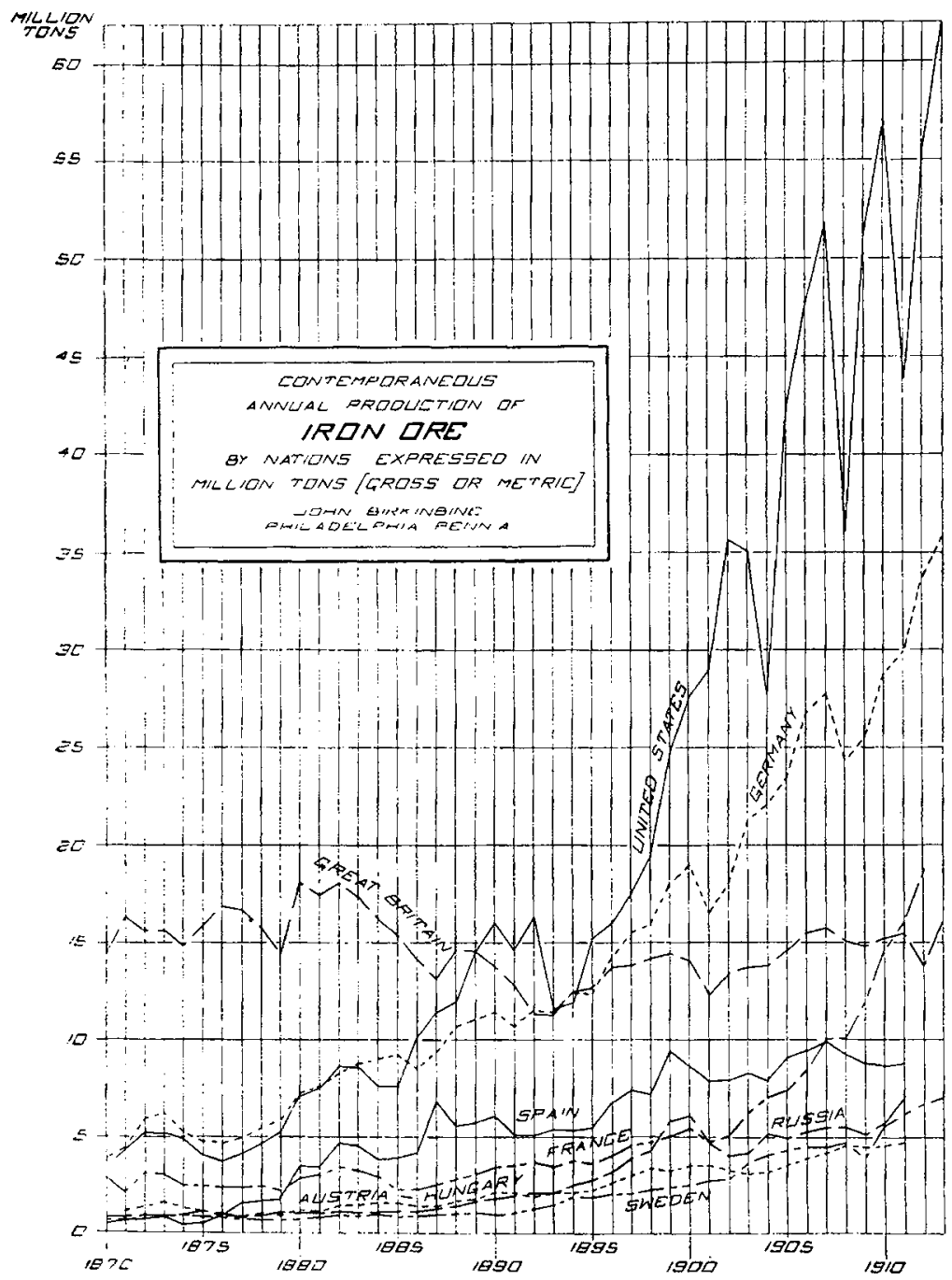

ing about one and a half million tons of iron ore annually, and smaller amounts are mined in Canada, China, Greece, Italy, Algeria, Belgium, Tunis, Australia, India, Japan, Norway, 
Mexico, Brazil, Chile and Korea. Iron ore exists in minable quantities in most of the geographical divisions of the earth and in some of these there are known reserves of enormous extent and of excellent quality.

The majority of iron ores obtained in Spain, Sweden, Russia, and the United States average higher percentages of iron than those in Great Britain, Austria-Hungary, Germany and Luxemburg, France, and Belgium. Hence the relative weights of iron ore obtained in the different countries may not be considered as equitably comparative, for two tons of ore containing 60 per cent. iron will produce as much metal as three tons of 40 per cent. ore. The world's output of iron ore approximates I 57,000,000 tons, the United States furnishing 36 per cent., and the nations now actively engaged in hostilities in Europe supplying an aggregate of 49 per cent. of the total iron ore product of the world. This resource is a most important factor, and it is asserted by some competent to judge that the control of the iron ore deposits of what was then eastern France and Luxemburg had a potential influence in the Franco-Prussian war of 1870 , and is a factor in the present conflict.

Pig Iron.

The graphic statement, Plate $B$, illustrates by ordinates, each space between horizontal lines representing $I, 000,000$ tons, the status of various countries as pig-iron producers subsequent to I869, and indicates by "curves" the annual contribution of each nation in tons.

The diagram shows that England, which had long been preeminent in pig-iron manufacture, was outstripped by the United States in 1890 , and that in 1903 Germany's product also exceeded that of Great Britain. Plate B, read in connection with Plate A, demonstrates that some important pig-iron producing countries depend to a greater or less extent upon other nations for iron ore, a feature which is later discussed.

Sweden, long celebrated for the excellence of its pig iron produced with charcoal as fuel, is included in Plate B, although its output is below, while those of all other nations shown on the diagram at present exceed $\mathrm{r}, 000,000$ tons of pig iron annually. It will be noted that the maximum production of pig iron in each of the nations discussed was obtained within the past four years. 
Plate B.

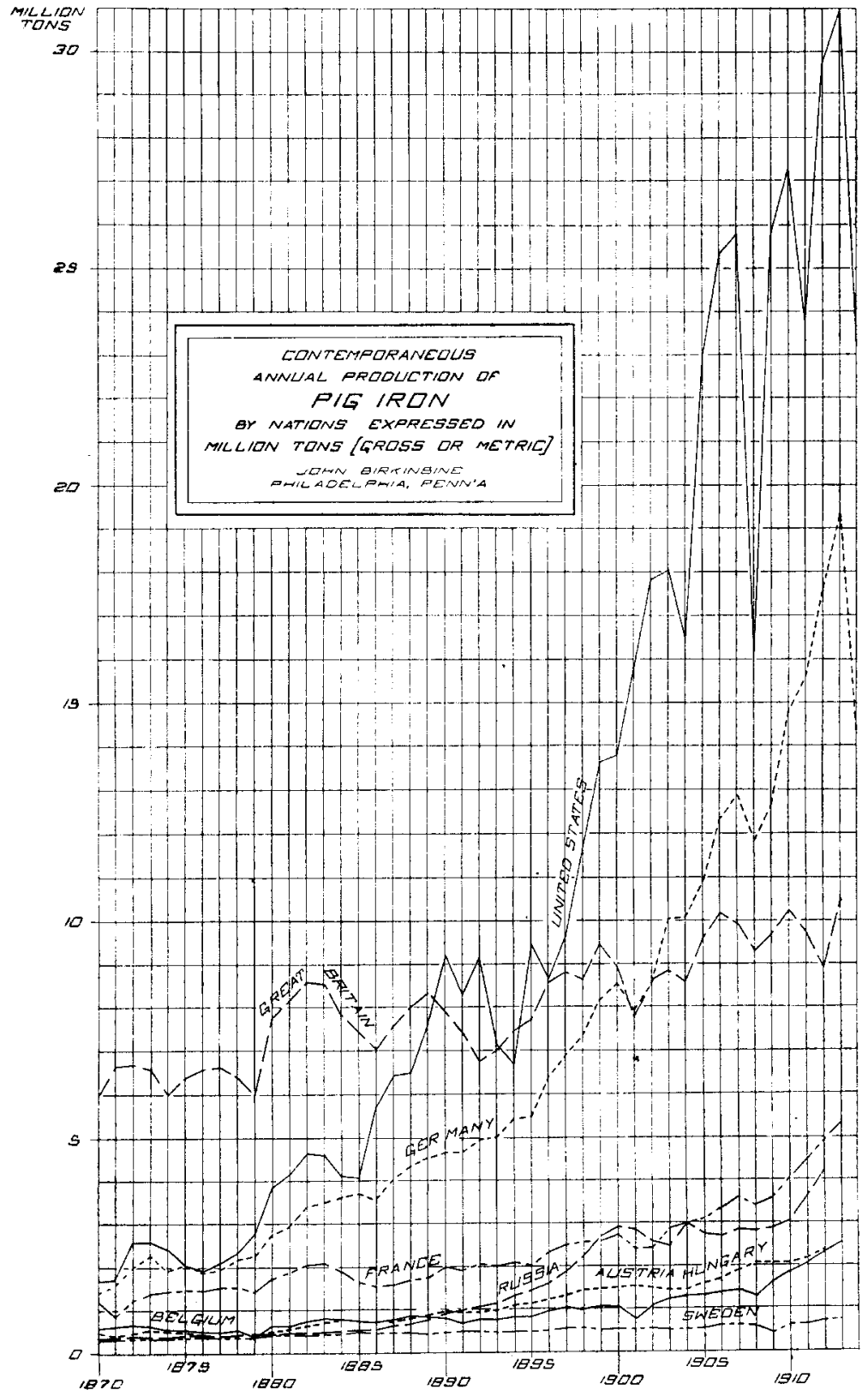


Among the countries supplying less than $1,000,000$ tons of pig iron per year are: Canada (contributing over a half million tons), Spain, Italy, Japan, China, India, and Mexico.

The production of pig iron indicates that various commercial forms of iron and steel into which it enters are also locally fabricated. The employment of liquid metal from blast furnaces for steel conversion, and of continuous processes of manipulation used in the manufacture of merchantable metal, causes the district which produces pig iron to attain prominence in supplying various forms of iron and steel, thereby advancing it as an important industrial factor.

To obtain pig iron, ores, fuels, fluxes, and air are required; the last named is sufficiently abundant to cause no anxiety, and fluxes represent a minor part of the " charge." But the average ton of pig iron demands for its production the consumption of two tons of ore and a ton or more of satisfactory fuel. Hence the nation having its own supply of iron ore, and ample metallurgical fuel of desirable quality, has an advantage in the race for industrial supremacy. The total quantity of pig iron produced throughout the world is in the neighborhood of $73,000,000$ tons. This is exclusive of metal obtained from forges by crude methods in a number of countries. Upon the above basis the United States at present supplies $4 \mathrm{I}$ per cent., and the combined output of the European nations in conflict is 55 per cent. of the world's pigiron product.

Coal.

Plate $\mathrm{C}$, which follows the form of Plates A and B, except that the spaces between horizontal lines represent 20,000,000 tons, illustrates the production of coal by various nations, and when read in connection with Plates $A$ and $B$ shows how different countries compare in the production and utilization of coal and iron ore.

England maintained preëminence in coal output until 1898 , but since that date the United States has been in the lead, and in I9I3 produced almost as much coal as its nearest competitors, Great Britain, Germany and Luxemburg, combined. The United States supplies more coal than all of continental Europe ; in fact, as much as the balance of the world excluding Great Britain39 per cent.

The coal product of the United States and Great Britain 
averages higher grade than that of continental Europe, where large quantities of lignite or brown coal are secured, but the

Plate C.

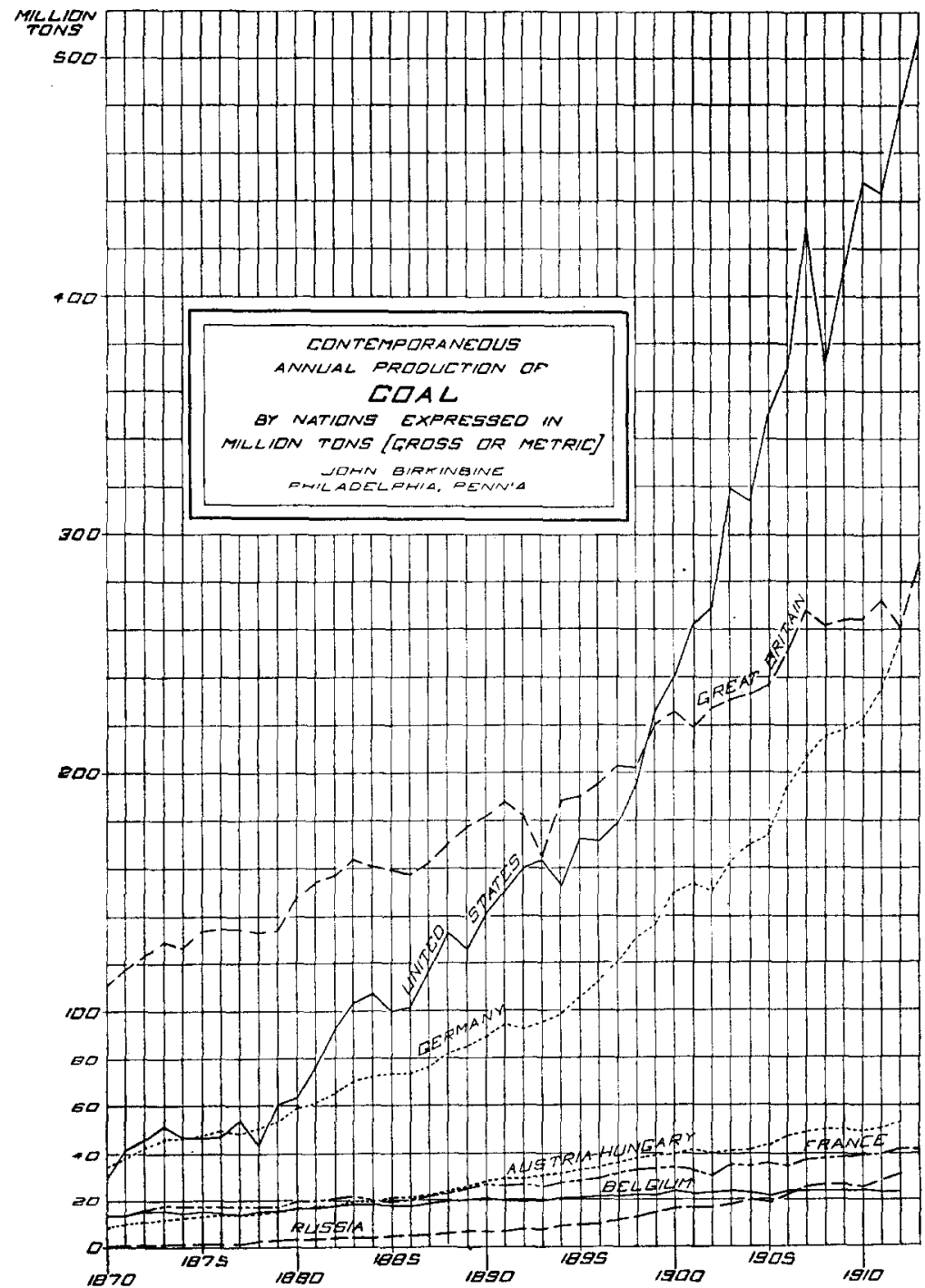

statistics given include the production of anthracite, bituminous, and lignite or brown coal. 
In Plate $\mathrm{C}$ only those countries contributing $20,000,000$ long or metric tons annually are indicated, but other countries mine large quantities of coal. Japan, China, India, and Canada each produces between 10,000,000 and 20,000,000 tons annually, and New South Wales, Spain, Transvaal, Natal, New Zealand, Mexico, Holland, and Chile each supplies between I, 000,000 and I0,000,000 tons yearly. About thirty countries produce smaller amounts.

In round numbers the total annual production of coal in the world at the present time is $1,250,000,000$ tons, of which the United States contributes between $3^{8}$ and 39 per cent., and the combined output of the European nations now at war approximates 50 per cent.

As supplementary to the three charts, the following statements are presented to show the position of each nation as a producer of iron ore, pig iron, and coal. To bring the statistics close to the present time, the obtainable records subsequent to the last census are given. The data are not completely contemporaneous, owing to the different periods for which information is available and to delays in making official statistics public.

The charts show that, according to latest official comparable data, the countries mentioned rank in volume of products in the following order:

Iron ore

United States,

Germany,

France,

Great Britain,

Spain,

Sweden,

Russia.
Pig iron

United States,

Germany,

Great Britain,

France,

Russia,

Austria-Hungary,

Belgium.
Coal

United States,

Great Britain,

Germany,

Austria-Hungary,

France,

Russia,

Belgium.

Analyses of these statements and of the three diagrams present some interesting, if not surprising, features.

The relative importance of the nations as producers of coal. iron ore, and pig iron is evident from the statistics presented, but the population of the countries and the relation which this bears to the quantities produced are of interest.

Thus, in per capita production, the nations rank: 
As producers of iron ore

Sweden,

United States,

Germany,

France,

Great Britain,

Austria-Hungary,

Russia.

\author{
As producers of pig iron \\ United States, \\ Belgium, \\ Germany, \\ Great Britain, \\ France, \\ Sweden, \\ Austria-Hungary, \\ Russia.
}

\author{
As producers of coal \\ Great Britain, \\ United States, \\ Germany, \\ Belgium, \\ France, \\ Austria-Hungary, \\ Japan, \\ Russia.
}

Progress in iron ore and coal mining, and in the manufacture of pig iron, between the years 1870 and 1910, shows as follows for the various countries, the quantities being quoted as per IO00 inhabitants :

In the interval of forty years the population of the United States increased from $38,500,000$ to $92,000,000$; its coal output rose from 765 to 4869 tons; its iron ores mined from 100 to 620 tons, and its pig iron made from 43 to 297 tons per 1000 inhabitants, the rate of increase being most pronounced in the last twenty years.

In the same period Great Britain's population advanced from $32,000,000$ to $45,000,000$, and its coal output increased from 3685 to 5994 tons, but its iron ore production decreased from $5^{1} 3$ to $34^{2}$ tons (in the decade ending 1901 to 292 tons). The amount of pig iron manufactured rose from 208 to 214 tons per 1000 inhabitants, reaching $23 \mathrm{I}$ tons in $\mathrm{I} 88 \mathrm{I}$.

In Germany and Luxemburg the population was augmented from $41,000,000$ in $187 \mathrm{I}$ to $66,000,000$ in I9ro; its coal output advanced from 922 to 3360 tons, its iron ore production from Io6 to 434 tons, and the pig iron manufactured from $3^{8}$ to 224 tons per rooo inhabitants.

In forty years the population of France advanced from $36,000,000$ to $39,600,000$, and contemporaneously its proportionate coal production grew from 438 to $99 \mathrm{I}$ tons, its iron ore output from 85 to 404 tons, and pig iron manufactured from 34 to I 13 tons per rooo inhabitants.

In Austria-Hungary the increase in population was from $36,000,000$ in 1870 to $49,000,000$ in I9I0. In the same interval its coal output was augmented from 233 to 989 tons, its iron ore product from 32 to 92 tons, and the amount of pig iron manufactured from $\mathrm{r}_{3}$ to $4 \mathrm{I}$ tons per rooo inhabitants.

From I 870 to 1912 the population of Russia has risen from

Vol. CLXXIX, No. I072-3I 
$85,000,000$ to $17 \mathrm{I}, 000,000$, and in that interval its coal mined advanced from 8 to $I 79$ tons, its iron ore output from 9 to $4 \mathrm{I}$ tons, and its pig iron manufactured from 4 to 24 tons per Iooo inhabitants.

Belgium produces but little iron ore, but, while its population advanced from $5,000,000$ in 1870 to $7,500,000$ in 1910 , its proportionate coal output rose from 2692 to 3222 tons, reaching 3505 tons in the year I 900 . This nation is a liberal manufacturer of pig iron, of which it produced I I tons in I 870 and 249 tons in I9Io per Iooo of population.

Sweden differs from Belgium in having but a small coal supply but an abundance of iron ore. In the forty years the population advanced from 4,000,000 to 5,500,000, its iron ore output, much of which is exported, rose from $\mathrm{I}_{5} \mathrm{I}$ to 1006 tons, and its pigiron production using charcoal as fuel from 72 to 109 tons per rooo inhabitants.

To illustrate the position of various nations as producers of coal, iron ore and pig iron, a series of statistical statements has been prepared covering the interval from 1870 to the present time. divided by decades. These show for each nation the total production in a decade, also the mean, maximum and minimum annual productions.

Reference has been made to the interdependence of nations, and, without attempting detailed explanation, this is epitomized in statements from latest data available of the amounts of iron ore, coal and pig iron exported and imported by various countries.

In the United States all iron ore produced, except about $I, 000,000$ tons annually exported to Canada, is smelted in the country, and in addition, in late years, from 2,000,000 to 2,600,ooo tons of iron ore are imported, principally from Cuba, Sweden, and New foundland.

The imports of pig iron and ferro alloys in late years into the United States range from 130,000 to 237 ,000 tons and the exports from 60,000 to 275,000 tons, showing that the domestic pig iron is used at home.

From $12,000,000$ to $22,000,000$ tons of coal are annually exported from and $I, 250,000$ to $2,000,000$ tons imported into the United States.

Germany and Luxemburg smelt their domestic iron ores, and in addition import $\mathrm{I}, 000,000$ to $\mathrm{I} 4,000,000$ tons, principally 
from Sweden, France, and Spain, and have exported about 2,500,000 tons, chiefly to Belgium and to France.

Germany annually imports I25,000 to I 40,000 tons, and exports in the neighborhood of $1,000,000$ tons of pig iron.

Thirty-one million to thirty-four million five hundred thousand tons of German coal are exported to Austria-Hungary, Holland, Belgium, France, Sweden, and Russia, and from $17,500,000$ to $18,500,000$ tons are imported into Germany.

Great Britain, in addition to its domestic iron ore supply, draws $6,000,000$ to nearly $8,000,000$ tons from foreign mines, two-thirds coming from Spain, although Algeria, Norway, Sweden, Tunis, Greece, and France contribute considerable quantities. No ore is exported.

Great Britain exports from I,000,000 to $2,000,000$ tons of pig iron, but the imports seldom exceed 250,000 tons.

Of its large fuel production, 65,000,000 tons of coal and about $1,000, \infty 00$ tons of coke are exported to continental European, South American, and other countries. Those receiving more than 5,000,000 tons of British fuel annually are France, Italy, Germany, Sweden, and Norway.

France.-Four million to over eight million tons of French iron ore are annually exported, principally to Belgium and Germany, and from I,O00,000 to 2,000,000 tons of iron ore are imported, mostly from Germany and Spain. France exported from I O0,000 to 250,000 tons of pig iron annually, while its imports of this metal are less than half these amounts.

France imports (mostly from England) about $16,000,000$ tons of coal and $2,000,000$ to $2,750,000$ tons of coke, while its fuel exports are from $1,300,000$ to $2,000,000$ tons.

Russia exports little iron ore, but about 4,000,000 tons of coal and 500,000 or more tons of coke are imported.

Austria-Hungary imports annually from 500,000 to 600,000 tons of iron ore, mainly from Sweden, and exports about roo,ooo tons, principally to Germany. From roo,ooo to 200,000 tons of pig iron are imported and 28,000 to 60,000 tons exported.

From 9,000,000 to $12,000,000$ tons of coal are imported, principally from Germany, and 8,000,000 tons, mostly lignite, are exported chiefly to Germany.

Spain is a large iron ore producer, and exports 7,000,000 to $9,000,000$ tons per year, the greater portion going to Great 
Britain. It produces 300,000 to 400,000 tons of pig iron, and its imports and exports are small. The domestic production of coal is augmented by importations of $2,000,000$ tons annually.

Belgium mines from 125,000 to 250,000 tons of iron ore annually, but imports mostly from France, Germany, and Spain $5,000,000$ to $6,000,000$ tons, about 500,000 tons of which are reëxported to Germany.

Belgium fabricates practically all of its pig-iron product, and also imports about two-thirds of a million tons annually, the larger part from Germany, although Great Britain and France also furnish pig iron. It mines from $22,000,000$ to $24,000,000$ tons of coal, imports $6,000,000$ to 7,500,000 tons, and exports about 5,00o,ooo tons, principally to France.

Sweden produces an abundance of high-grade iron ore, the greater part of which is exported to Germany, England, Belgium, and the United States. The pig-iron industry depends almost entirely on charcoal, about one-fourth of the production being exported.

The various nations have been discussed independently of any colonies or dependencies, for, as before stated, the pig iron made has not been followed through mills and factories. But the statements presented may indicate how intimate the association has been between nations now combating each other and seeking to cripple their adversaries in every possible manner. These may also suggest the present and prospective status of each country as a contributor to the supply of resources necessary for the world's advancement, and show how changes of boundary lines may enlarge or reduce the independent manufacturing possibilities of the nations now at war.

On preceding pages reference has been made to the necessary interchange of the raw or the manufactured materials between the countries now at conflict, and it is possible that the result of the war may greatly strengthen some or seriously cripple others of the contestants, according to the peace terms which may be agreed upon. The commercial supremacy of each nation is, to a great extent, controlled by its ability to manufacture articles of iron and steel.

The effects of such changes may extend far beyond the limits of the countries contending with each other, and the possession of natural reserves of some nations or colonies and also in the Orient may be more than a mere incident in the European War. 
PRODUCTION OF IRON ORE in the Eight Principal Iron-Ore Mining Countries in the World, from 1870 to 1913, by Ten-year Periods.

UNITED States-Long Tons.

\begin{tabular}{|c|c|c|c|c|c|c|}
\hline Period & $\begin{array}{l}\text { Total } \\
\text { production }\end{array}$ & $\begin{array}{l}\text { Mean } \\
\text { annual } \\
\text { production }\end{array}$ & Year & Maximum & Year & Minimum \\
\hline $\left.\begin{array}{r}1870 \\
1879\end{array}\right\}$ & $44,645,440$ & $4,464,544$ & 1879 & $5,255,000$ & 1876 & $3,734,000$ \\
\hline $\left.\begin{array}{l}1880 \\
1889\end{array}\right\}$ & $95,089,403$ & $9,508,940$ & I 889 & $14,518,041$ & 1880 & $7,120,362$ \\
\hline $\left.\begin{array}{l}1890 \\
1899\end{array}\right\}$ & $163,989,193$ & $16,398,919$ & 1899 & $24,683,173$ & 1893 & I $1,587,629$ \\
\hline $\left.\begin{array}{l}1900 \\
1909\end{array}\right\}$ & $383,932,500$ & $3^{8,393,250}$ & 1907 & $51,720,619$ & 1900 & $27,553,16 r$ \\
\hline $\left.\begin{array}{l}\text { 1910 } \\
\text { 1913 }\end{array}\right\}$. & $218,022,042$ & $54,505,510$ & 1913 & $61,980,437$ & $9 I I$ & 43,8 \\
\hline
\end{tabular}

Germany AND LuXemburg-Metric Tons.

\begin{tabular}{|c|c|c|c|c|c|c|}
\hline erio & $\begin{array}{l}\text { Total } \\
\text { production }\end{array}$ & 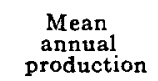 & Year & Maximum & Year & Minimum \\
\hline $\left.\begin{array}{l}1870 \\
1879\end{array}\right\}$ & $5 \mathrm{I}, 160,84^{2}$ & $5,116,084$ & 1873 & $6,177,576$ & 1870 & $3,839,222$ \\
\hline $\left.\begin{array}{l}1880 \\
1889\end{array}\right\}$ & $89,499,306$ & $8,949,93$ I & I 889 & $11,002,187$ & 1880 & $7,23^{8,640}$ \\
\hline $\begin{array}{l}1890 \\
1899\end{array}$ & $133,313,059$ & $13,331,306$ & 1899 & $17,989,635$ & 1891 & $10,657,521$ \\
\hline $\left.\begin{array}{l}1900 \\
1909\end{array}\right\}$ & $224,434,495$ & $22,443,450$ & 1907 & $27,697,127$ & I90I & $16,570,182$ \\
\hline $\begin{array}{l}1910 \\
1013\end{array}$ & I $28,284,2$ I 2 & $32,071,053$ & 1913 & $35,941,285$ & 1910 & $28,729,700$ \\
\hline
\end{tabular}

Great Britain-Long Tons.

\begin{tabular}{|c|c|c|c|c|c|c|}
\hline ariod & $\begin{array}{c}\text { Total } \\
\text { production }\end{array}$ & $\begin{array}{c}\text { Mean } \\
\text { annual } \\
\text { production }\end{array}$ & Year & Maximum & Year & Minimum \\
\hline $\left.\begin{array}{l}870 \\
879\end{array}\right\}$ & $156,173,886$ & $15,617,389$ & 1876 & I $6,841,5^{84}$ & 1870 & $14,370,655$ \\
\hline 880$\}$ & $\mathrm{I} 58,823,859$ & $15,882,386$ & 1882 & $18,031,957$ & 1887 & I $3,098,04 \mathrm{I}$ \\
\hline $\left.\begin{array}{l}890 \\
899\end{array}\right\}$ & $130,184,239$ & $13,018,424$ & 1899 & $14,461,330$ & 1893 & I $1,203,476$ \\
\hline 9009 & $142,877,457$ & $I 4,287,746$ & 1907 & I $5,731,604$ & I9or & $12,275,198$ \\
\hline $\left.\begin{array}{l}910 \\
913\end{array}\right\}$ & $60,533,15^{8}$ & I $5,133,290$ & I9I3 & $15,997,328$ & I9I2 & $13.790,391$ \\
\hline \multicolumn{7}{|c|}{ France-Metric Tons. } \\
\hline eriod & $\begin{array}{l}\text { Total } \\
\text { production }\end{array}$ & $\begin{array}{c}\text { Mean } \\
\text { annual } \\
\text { production }\end{array}$ & Year & Maximum & Year & Minimum \\
\hline $\left.\begin{array}{l}870 \\
879\end{array}\right\}$ & $25,715,612$ & $2,571,561$ & 1872 & $3,081,026$ & I $87 \mathrm{I}$ & $2,099,706$ \\
\hline 880$\}$ & $28,743,748$ & $2,874,375$ & 1882 & $3,467,251$ & I886 & $2,285,648$ \\
\hline $\left.\begin{array}{l}890 \\
899\end{array}\right\}$ & $40,088,780$ & $4,008,878$ & 1899 & $4,985,702$ & I 890 & $3,471,718$ \\
\hline $\left.\begin{array}{l}1900 \\
1909\end{array}\right\}$ & $76,317,045$ & $7,631,705$ & 1909 & I $1,890,000$ & 1902 & $5,003,782$ \\
\hline $\left.\begin{array}{l}910 \\
912\end{array}\right\}$ & $49,410,07^{8}$ & $16,47^{0}, 026$ & 1912 & $18,800,000$ & 1910 & I $4,605,542$ \\
\hline
\end{tabular}


PRODUCTION OF IRON ORE in the Eight Principal Iron-Ore Mining Countries in the World, from 1870 to IOI3, by Ten-year Periods.-Continued.

SpaIN-Metric Tons.

\begin{tabular}{|c|c|c|c|c|c|c|}
\hline riod & $\begin{array}{c}\text { Total } \\
\text { production }\end{array}$ & 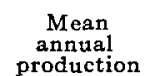 & Year & Maximum & Year & Minimum \\
\hline$\{70\}$ & $9,419,302$ & 941,930 & 1874 & 423,401 & 1877 & $\mathrm{I}, 578, \mathrm{I} 50$ \\
\hline $\left.\begin{array}{l}880 \\
889\end{array}\right\}$. & $46,444,883$ & $4,644,488$ & 1887 & $6,796,266$ & I $88 \mathrm{I}$ & $3,502,681$ \\
\hline $\left.\begin{array}{l}1890 \\
899\end{array}\right\}$ & $63,292,106$ & $6,329,2$ I I & I 899 & $9,397,733$ & 1892 & $5,041,317$ \\
\hline $\left.\begin{array}{l}900 \\
909\end{array}\right\}$ & $87,235,290$ & $8,723,529$ & 1907 & 9,896, I 78 & 1902 & $7,904,555$ \\
\hline $\left.\begin{array}{l}\text { I910 } \\
\text { IOII }\end{array}\right\}$. & $17,440,486$ & $8,720,243$ & 1911 & $8,773,691$ & I910 & $8,666,795$ \\
\hline
\end{tabular}

Russian EMPIRE-Metric Tons.

\begin{tabular}{|c|c|c|c|c|c|c|}
\hline Period & $\begin{array}{c}\text { Total } \\
\text { production }\end{array}$ & $\begin{array}{c}\text { Mean } \\
\text { annual } \\
\text { production }\end{array}$ & Year & Maximum & Year & Minimum \\
\hline $\left.\begin{array}{l}1870 \\
1879\end{array}\right\}$. & $9,166,008$ & 916,601 & I 875 & $1,056,545$ & 1871 & 794,779 \\
\hline $\left.\begin{array}{l}1880 \\
1889\end{array}\right\}$ & $11,692,556$ & $\mathrm{I}, \mathrm{I} 69,25^{6}$ & 1889 & $I, 646,840$ & 1883 & 998,393 \\
\hline $\left.\begin{array}{l}1890 \\
1899\end{array}\right\}$ & 30,468, OI I & $3,046,801$ & I 899 & $5,788,709$ & I 890 & $\mathrm{I}, 802,165$ \\
\hline $\left.\begin{array}{l}1900 \\
1909\end{array}\right\}$ & $50,621,536$ & $5,062,154$ & 1900 & $6,122,270$ & 1902 & $4,004,007$ \\
\hline $\left.\begin{array}{l}1910 \\
1911\end{array}\right\}$ & $12,750,218$ & $6,375,109$ & I9I I & $6,985,039$ & 1910 & $5,765,179$ \\
\hline \multicolumn{7}{|c|}{$\begin{array}{l}\text { SwEDEN-Metric Tons. } \\
\text { Mean }\end{array}$} \\
\hline $\left.\begin{array}{l}\text { Period } \\
1870 \\
1879\end{array}\right\}$ & $\begin{array}{c}\text { Total } \\
\text { production } \\
7,466,982\end{array}$ & $\begin{array}{c}\text { annual } \\
\text { production } \\
746,698\end{array}$ & $\begin{array}{l}\text { Year } \\
\text { I } 874\end{array}$ & $\begin{array}{r}\text { Maximum } \\
926,825\end{array}$ & $\begin{array}{l}\text { Year } \\
\text { I870 }\end{array}$ & $\begin{array}{r}\text { Minimum } \\
630,739\end{array}$ \\
\hline $\left.\begin{array}{l}1880 \\
1889\end{array}\right\}$. & $8,883,492$ & 888,349 & I 889 & 985,904 & I 880 & 775,344 \\
\hline $\left.\begin{array}{l}1890 \\
1899\end{array}\right\}$ & $\mathrm{I} 7,402, \mathrm{I} 64$ & $\mathrm{I}, 740,2 \mathrm{I} 6$ & 1899 & $2,435,200$ & I 890 & $94 \mathrm{I}, 241$ \\
\hline $\left.\begin{array}{l}1900 \\
1909\end{array}\right\}$ & $3^{8,0 \text { I I,6I } 8}$ & $3,801,162$ & 1908 & $4,7 \mathrm{I} 3, \mathrm{r} 60$ & 1900 & $2,609,500$ \\
\hline $\left.\begin{array}{l}1910 \\
1913\end{array}\right\}$ & $25,886,414$ & $6,47 \mathrm{I}, 604$ & 1913 & $7,479,393$ & rgro & $5,552,678$ \\
\hline
\end{tabular}

Austria-Hungary-Metric Tons.

\begin{tabular}{|c|c|c|c|c|c|c|}
\hline d & $\begin{array}{c}\text { Total } \\
\text { production }\end{array}$ & $\begin{array}{c}\text { Mean } \\
\text { annual } \\
\text { production }\end{array}$ & Year & Maximum & Year & Minimum \\
\hline $\left.\begin{array}{l}371 \\
379\end{array}\right\}$. & $10,246,331$ & $\mathbf{I}, \mathbf{I} 38,4^{8} \mathbf{I}$ & I 873 & $r, 5^{88,05^{8}}$ & I 877 & 884,260 \\
\hline $\left.\begin{array}{l}380 \\
389\end{array}\right\}$. & $14,632,594$ & $1,463,259$ & I 889 & $1,780,772$ & I88I & $1,084,443$ \\
\hline $\left.\begin{array}{r}1890 \\
1899\end{array}\right\}$ & $25,162,976$ & $2,516,298$ & I 899 & $3,293,004$ & I 892 & $\mathrm{I}, 913,83 \mathrm{I}$ \\
\hline $\left.\begin{array}{l}900 \\
909\end{array}\right\}$. & $37,511,679$ & $3,751,168$ & 1908 & $4,568,814$ & 1903 & $3,155,1 \times 6$ \\
\hline $\left.\begin{array}{l}\text { I910 } \\
\text { I91 }\end{array}\right\}$. & $9,245,998$ & $4,622,999$ & 191I & $4,712,666$ & 1910 & $4,533,332$ \\
\hline
\end{tabular}


PRODUCTION OF PIG IRON in the Eight Principal Pig-iron Producing Countries in the World, from 1870 to 1914, by Ten-year Periods.

UNITED STATES-Long Tons.

\begin{tabular}{|c|c|c|c|c|c|c|}
\hline Periad & $\begin{array}{l}\text { Total } \\
\text { production }\end{array}$ & $\begin{array}{l}\text { Mean } \\
\text { annual } \\
\text { production }\end{array}$ & Year & Maximum & Year & Minimum \\
\hline $\left.\begin{array}{l}1870 \\
1879\end{array}\right\}$ & $21,885,266$ & $2,188,527$ & I 879 & $2,741,853$ & 1870 & $1,665,179$ \\
\hline $\left.\begin{array}{l}1880 \\
1889\end{array}\right\}$ & $51,534,529$ & $5,153,453$ & 1889 & $7,603,642$ & 1880 & $3,835, \mathrm{rg} I$ \\
\hline $\left.\begin{array}{l}1890 \\
1899\end{array}\right\}$ & $93,538,215$ & $9,353,822$ & I 899 & $13,620,703$ & 1894 & $6,657,3^{88}$ \\
\hline $\left.\begin{array}{l}1900 \\
1909\end{array}\right\}$ & $197,807,609$ & r9,780,76r & 1909 & $25,795,471$ & rgoo & $13,7^{89,242}$ \\
\hline $\left.\begin{array}{l}1910 \\
1914\end{array}\right\}$. & I $34,978,77^{6}$ & $26,995,755$ & 1913 & $30,966,30 \mathrm{I}$ & I9I 4 & $23,332,244$ \\
\hline
\end{tabular}

Germany and LuXemburg-Metric Tons.

\begin{tabular}{|c|c|c|c|c|c|c|}
\hline Peri & $\begin{array}{l}\text { Total } \\
\text { production }\end{array}$ & $\begin{array}{c}\text { Mean } \\
\text { annual } \\
\text { production }\end{array}$ & Year & Maximum & Year & Minimum \\
\hline $\left.\begin{array}{l}1870\} \\
1879\end{array}\right\}$. & $19,272,726$ & $\mathrm{I}, 927,273$ & 1873 & $2,240,575$ & 1870 & I,391,124 \\
\hline $\left.\begin{array}{l}1880 \\
1889\end{array}\right\}$ & $36,195,906$ & $3,619,591$ & I 889 & $4,524,55^{8}$ & I 880 & $2,729,038$ \\
\hline $\left.\begin{array}{l}1890 \\
1899\end{array}\right\}$ & $58,777,609$ & $5,877,76 \mathrm{I}$ & I 899 & $8, \mathrm{I} 43, \mathrm{I} 32$ & I 89 I & $4,641,217$ \\
\hline $\begin{array}{l}1900\} \\
1909\}\end{array}$ & $105,500,005$ & $10,550,001$ & 1907 & $12,875,159$ & I90X & $7,880,087$ \\
\hline $\left.\begin{array}{l}1910 \\
1914\end{array}\right\}$ & $81,683,742$ & $16,336,748$ & 1913 & $19,309,172$ & 1914 & 14.389 .547 \\
\hline
\end{tabular}

Great Britain-Long Tons.

\begin{tabular}{|c|c|c|c|c|c|c|}
\hline Period & $\begin{array}{l}\text { Total } \\
\text { production }\end{array}$ & $\begin{array}{l}\text { Mean } \\
\text { annual } \\
\text { production }\end{array}$ & Year & Maximum & Year & Minimum \\
\hline $\left.\begin{array}{l}1870 \\
1879\end{array}\right\}$ & $63,796,993$ & $6,379,699$ & 1872 & $6,741,929$ & 1870 & $5,963,515$ \\
\hline $\left.\begin{array}{l}1880 \\
1889\end{array}\right\}$ & $79,127,923$ & $7,912,792$ & 1882 & $8,586,680$ & I 886 & $7,009,754$ \\
\hline $\left.\begin{array}{l}1890 \\
1899\end{array}\right\}$ & $79,614,624$ & $7,961,462$ & 1899 & $9,42 \mathrm{I}, 435$ & 1892 & $6,709,255$ \\
\hline $\left.\begin{array}{l}1900 \\
1909\end{array}\right\}$ & $91,251,065$ & $9,125,107$ & 1906 & I0,I 49,388 & I90I & $7,761,832$ \\
\hline $\begin{array}{l}10 \\
13\end{array}$ & $39,306,601$ & $9,826,650$ & 1913 & $10,48 \mathrm{I}, 917$ & 1912 & $8,889,124$ \\
\hline rio & $\begin{array}{l}\text { Total } \\
\text { production }\end{array}$ & $\begin{array}{l}\text { FraNCE- } \\
\text { Mean } \\
\text { annual } \\
\text { production }\end{array}$ & Metric & Tons. & Year & Minimum \\
\hline $\begin{array}{l}770 \\
799\end{array}$ & $13,364,987$ & $1,336,499$ & 1878 & $\mathrm{I}, 52 \mathrm{I}, 274$ & I87I & 859,641 \\
\hline $\left.\begin{array}{l}1880 \\
1889\end{array}\right\}$ & $17,723,834$ & $1,77^{2,383}$ & I 883 & $2,069,430$ & I 886 & $x, 516,574$ \\
\hline $\left.\begin{array}{l}1890 \\
1899\end{array}\right\}$ & $21,919,062$ & $2,191,906$ & I 899 & $2,567,388$ & I89I & $1,897,387$ \\
\hline $\begin{array}{l}1900\} \\
1909\end{array}$ & $30,278,382$ & $3,027,838$ & 1907 & $3,590,235$ & I9or & $2,388,823$ \\
\hline $\left.\begin{array}{l}1910 \\
1913\end{array}\right\}$ & $18,758,948$ & $4,689,737$ & 1913 & $5,311,316$ & 1910 & $4,038,297$ \\
\hline
\end{tabular}


PRODUCTION OF PIG IRON in the Eight Principal Pig-iron Producing Countries in the World, from 187 a to 1914, by Ten-year Periods.-Continued.

Russia-Metric Tons.

\begin{tabular}{|c|c|c|c|c|c|c|}
\hline riod & $\begin{array}{c}\text { Total } \\
\text { production }\end{array}$ & $\begin{array}{l}\text { Mean } \\
\text { annual } \\
\text { production }\end{array}$ & Year & Maximum & Year & Minimum \\
\hline $\left.\begin{array}{l}870 \\
879\end{array}\right\}$ & $3,805,983$ & 380,598 & I879 & 420,660 & 1871 & 339,513 \\
\hline $\left.\begin{array}{l}880 \\
889\end{array}\right\}$ & $5,278,717$ & 527,872 & 1889 & 733,720 & 1880 & 427,696 \\
\hline $\left.\begin{array}{l}1890 \\
1899\end{array}\right\}$ & 15, I I 3,846 & $1,511,385$ & I 899 & $2,677,120$ & 1890 & 905,460 \\
\hline $\begin{array}{l}900 \\
901\end{array}$ & $27,634,376$ & $2,763,43^{8}$ & 1904 & $2,962,283$ & 1903 & $2,449,70 \mathrm{I}$ \\
\hline $\left.\begin{array}{l}1910 \\
1912\end{array}\right\}$ & $10,830,846$ & $3,6 \mathrm{I} 0,282$ & 1912 & $4,197,635$ & 1910 & $3,040,047$ \\
\hline
\end{tabular}

Austria-HungarX-Metric Tons.

\begin{tabular}{|c|c|c|c|c|c|c|}
\hline Period & $\begin{array}{l}\text { Total } \\
\text { production }\end{array}$ & $\begin{array}{c}\text { Mean } \\
\text { annual } \\
\text { production }\end{array}$ & Year & Maximum & Year & Minimum \\
\hline $\left.\begin{array}{l}1870 \\
1879\end{array}\right\}$ & $4,423,447$ & 442,345 & I 873 & 534,508 & 1877 & 387,630 \\
\hline $\left.\begin{array}{l}1880 \\
1889\end{array}\right\}$ & $6,838,15^{8}$ & 683,816 & 1889 & 855,822 & 1880 & 464,234 \\
\hline $\left.\begin{array}{l}1890 \\
1899\end{array}\right\}$ & II $, 431,25^{8}$ & $1,143,126$ & I 899 & $I, 467,664$ & 1891 & $921,84^{6}$ \\
\hline $\left.\begin{array}{l}1900 \\
1909\end{array}\right\}$ & I6,I I 9,729 & $I, 611,973$ & 1909 & $1,995,511$ & 1904 & $I, 375,865$ \\
\hline $\left.\begin{array}{l}1910 \\
1912\end{array}\right\}$ & $6,545,212$ & $2,181,737$ & 1912 & $2,372,660$ & 1910 & $2,060,975$ \\
\hline \multicolumn{7}{|c|}{ Belgium-Metric Tons. } \\
\hline eriod & $\begin{array}{c}\text { Total } \\
\text { production }\end{array}$ & $\begin{array}{c}\text { Mean } \\
\text { annual } \\
\text { production }\end{array}$ & Year & Maximum & Year & Minimum \\
\hline $\left.\begin{array}{l}1870 \\
1879\end{array}\right\}$ & $5,379,203$ & 537,920 & 1872 & 655,565 & 1879 & $3^{89,33^{\circ}}$ \\
\hline $\left.\begin{array}{l}1880 \\
1889\end{array}\right\}$ & $7,323,42 \mathrm{I}$ & 732,342 & 1889 & 832,226 & 1880 & 608,084 \\
\hline $\begin{array}{l}\text { I } 890 \\
\text { I } 899\end{array}$ & $8,631,404$ & $863, \mathrm{I} 40$ & I 899 & $\mathrm{I}, 036,185$ & 1891 & 684,126 \\
\hline $\left.\begin{array}{l}1900 \\
1909\end{array}\right\}$ & $12,335,7^{66}$ & $1,233,577$ & I909 & $1,616,37^{\circ}$ & I90I & 764,180 \\
\hline $\left.\begin{array}{l}\text { rgro } \\
\text { 1913 }\end{array}\right\}$ & $8,726,830$ & $2,18 \mathrm{I}, 708$ & 1913 & $2,527,070$ & 1910 & $1,852,090$ \\
\hline \multicolumn{7}{|c|}{ SwEDEN-Metric Tons. } \\
\hline Period & $\begin{array}{l}\text { Total } \\
\text { production }\end{array}$ & $\begin{array}{l}\text { Mean } \\
\text { annua1 } \\
\text { production }\end{array}$ & Year & Maximum & Year & Minimum \\
\hline $\begin{array}{l}1870 \\
1879\end{array}$ & $3,343,027$ & 334,303 & I 876 & 352,467 & 1871 & $298,76 \mathrm{r}$ \\
\hline $\begin{array}{l}1880 \\
1889\end{array}$ & $4,329,398$ & 432,940 & I 885 & 464,737 & 1882 & 398,945 \\
\hline $\begin{array}{l}1890 \\
1899\end{array}$ & $4,873,948$ & 487,395 & I 897 & 538,197 & 1893 & $453,42 \mathrm{I}$ \\
\hline 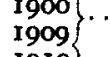 & $5,401,295$ & 540, I 30 & 1907 & 615,778 & 1909 & 444,764 \\
\hline $\left.\begin{array}{l}1910 \\
1913\end{array}\right\}$ & $2,668,404$ & 667,101 & 1913 & 730,257 & 1910 & 603,939 \\
\hline
\end{tabular}


PRODUCTION OF COAL in the Eight Principal Coal-Mining Countries in the World, from I870 to I9I3, by Ten-year Periods.

\begin{tabular}{|c|c|c|c|c|c|c|}
\hline \multirow{3}{*}{$\left.\begin{array}{l}\text { Period } \\
1870 \\
1879\end{array}\right\}$} & \multicolumn{6}{|c|}{ United States-Long Tons. } \\
\hline & $\begin{array}{l}\text { Total } \\
\text { production }\end{array}$ & $\begin{array}{c}\text { Mean } \\
\text { annual } \\
\text { production }\end{array}$ & Year & Maximum & Year & Minimum \\
\hline & $476,566,017$ & $47,656,602$ & I 879 & $60,808,749$ & 1870 & $29,496,054$ \\
\hline $\left.\begin{array}{l}1880 \\
1889\end{array}\right\}$ & . . I,019,753,264 & IoI $, 975,326$ & I 888 & I $32,701,827$ & 1880 & $63,822,830$ \\
\hline $\left.\begin{array}{l}1890 \\
1899\end{array}\right\}$ & $\ldots 1,712,331,738$ & I $71,233,174$ & I 899 & $226,554,635$ & 1890 & $I 40,866,93 \mathrm{I}$ \\
\hline $\left.\begin{array}{l}1900 \\
1909\end{array}\right\}$ & $\cdots 3,337,185,5^{89}$ & $333,718,559$ & 1907 & $428,895,914$ & 1900 & $240,789,310$ \\
\hline 1910$\}$ & $\ldots \mathrm{I}, 877,082,366$ & 469,270 & 1913 & $508,971,540$ & I9II & $443,054,614$ \\
\hline
\end{tabular}

Great Britain-Long Tons.

\begin{tabular}{|c|c|c|c|c|c|c|}
\hline eriod & $\begin{array}{c}\text { Total } \\
\text { production }\end{array}$ & $\begin{array}{l}\text { Mean } \\
\text { annual } \\
\text { production }\end{array}$ & Year & Maximum & Year & Minimum \\
\hline $\left.\begin{array}{l}1870 \\
1879\end{array}\right\}$ & $\mathrm{I}, 274,494,850$ & $127,449,485$ & I 877 & $134, \mathrm{I} 79,968$ & 1870 & I I 0,431, I92 \\
\hline $\left.\begin{array}{l}1880 \\
1889\end{array}\right\}$ & $\mathbf{1}, 607,990,447$ & $160,799,045$ & 1889 & I $76,916,724$ & $\mathrm{I} 880$ & $146,969,409$ \\
\hline $\left.\begin{array}{l}1890 \\
1899\end{array}\right\}$ & $. \mathrm{I}, 910,785,455$ & $\mathrm{I} 91,078,546$ & I 899 & $220,094,781$ & 1893 & $164,325,795$ \\
\hline $\left.\begin{array}{l}900 \\
909\end{array}\right\}$ & $.2,414,416,66 \mathrm{I}$ & $24 I, 441,666$ & 1907 & $267,830,962$ & I90I & $219,046,945$ \\
\hline 10 & $.1,084,171,738$ & $271,042,935$ & 1913 & $287,430,473$ & 1912 & $260,416,338$ \\
\hline \multicolumn{7}{|c|}{ GERMANY-Metric Tons. } \\
\hline eriod & $\begin{array}{l}\text { Total } \\
\text { production }\end{array}$ & $\begin{array}{l}\text { Mean } \\
\text { annual } \\
\text { production }\end{array}$ & Year & Maximum & Year & Minimum \\
\hline $\left.\begin{array}{l}870 \\
879\end{array}\right\}$ & $456,561,932$ & $45,656,193$ & 1879 & $53,470,716$ & 1870 & $34,003,004$ \\
\hline $\begin{array}{l}880 \\
889\end{array}$ & $719,117,229$ & $71,911,723$ & I889 & $84,973,230$ & I 880 & $59,118,035$ \\
\hline $\begin{array}{l}1890 \\
1899\end{array}$ & . I,073,735,837 & $107,373,5^{84}$ & I 899 & I $35,824,427$ & 1890 & $89,051,527$ \\
\hline $\begin{array}{l}1900 \\
1909\end{array}$ & I , $791,128,249$ & I 79, I I 2,825 & 1909 & $217,445,656$ & 1900 & $149,788,256$ \\
\hline $\left.\begin{array}{l}1910 \\
1912\end{array}\right\}$ & $711,706,424$ & $237,235,475$ & 1912 & $255,810,094$ & 1910 & $222,375,076$ \\
\hline \multicolumn{7}{|c|}{$\begin{array}{l}\text { FraNCE-Metric Tons. } \\
\text { Mean }\end{array}$} \\
\hline eriod & $\begin{array}{l}\text { Total } \\
\text { production }\end{array}$ & $\begin{array}{l}\text { annual } \\
\text { production }\end{array}$ & Year & Max & Year & Minimum \\
\hline $\left.\begin{array}{r}1870 \\
1879\end{array}\right\}$ & $161,713,709$ & $16,17 x, 371$ & 1873 & $\mathrm{I} 7,479,34 \mathrm{I}$ & 1871 & $13,258,920$ \\
\hline $\left.\begin{array}{l}1880 \\
1889\end{array}\right\}$ & 703,065 & $20,870,307$ & 1889 & $24,303,509$ & I88I & $19,361,564$ \\
\hline 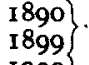 & . $286,581,124$ & $28,658,112$ & I 899 & $32,863,000$ & I 893 & $25,650,981$ \\
\hline$[900\}$ & $346,903,640$ & $34,690,364$ & I909 & $37,840,086$ & 1902 & $29,997,470$ \\
\hline $\left.\begin{array}{l}1910 \\
1913\end{array}\right\}$ & $\ldots \quad 159,716,914$ & $39,929,229$ & 1912 & $41,145,178$ & 1910 & $38,349,942$ \\
\hline
\end{tabular}


PRODUCTION OF COAL in the Eight Principal Coal-Mining Countries in the World, from 1870 to I9I3 by to-year periods.

\begin{tabular}{|c|c|c|c|c|c|c|}
\hline \multirow{5}{*}{$\left.\begin{array}{l}\text { Period } \\
1870 \\
1879 \\
1880 \\
1889 \\
1890 \\
1899\end{array}\right\}$} & \multicolumn{5}{|c|}{ Austria-Hungary-Metric Tons. } & \multirow{3}{*}{$\begin{array}{c}\cdot \\
\text { Minimum } \\
8,355,944\end{array}$} \\
\hline & $\begin{array}{l}\text { Total } \\
\text { production }\end{array}$ & $\underset{\substack{\text { Mean } \\
\text { annual } \\
\text { production }}}{ }$ & Year & Maximum & Yeat & \\
\hline & $121,822,412$ & $12,182,24 \mathrm{I}$ & 1879 & $14,891,024$ & 1870 & \\
\hline & $202,43^{\circ}, 110$ & $20,243,01$ I & I 889 & $25,328,4 \mathrm{I} 7$ & 1880 & $16,128,7$ I 8 \\
\hline & $325,647,572$ & $3^{2}, 564,757$ & 1899 & $3^{8,739,000}$ & I 890 & $27,504,032$ \\
\hline $\left.\begin{array}{l}1900 \\
1909\end{array}\right\}$ & 439,7 19,257 & $43,97 I, 926$ & 1908 & $49,626,184$ & 1900 & $39,502,301$ \\
\hline $\left.\begin{array}{l}910 \\
912\end{array}\right\}$ & $15 I, 031,218$ & $50,343,739$ & 1912 & $52,521,776$ & I9Io & $48,649,768$ \\
\hline \multicolumn{7}{|c|}{ Russia-Metric Tons. } \\
\hline iriod & $\begin{array}{l}\text { Total } \\
\text { production }\end{array}$ & $\begin{array}{l}\text { Mean } \\
\text { annual } \\
\text { production }\end{array}$ & Year & Maximum & Year & Minimum \\
\hline $\begin{array}{l}870 \\
870\end{array}$ & I $5,555,667$ & $I, 555,567$ & 1879 & $2,874,790$ & 1870 & 696,673 \\
\hline 380$\}$ & $43,237,790$ & $4,323,779$ & 1889 & $6,213,869$ & 1880 & $3,286,534$ \\
\hline $\begin{array}{l}390 \\
999\end{array}$ & $91,966,854$ & $9,196,685$ & I 899 & $14,311,200$ & 1890 & $6,085,080$ \\
\hline 300 & $204,227,25 \mathrm{I}$ & $0,422,725$ & 1909 & $26,075,086$ & I900 & $16,135,600$ \\
\hline $\left.\begin{array}{l}910 \\
912\end{array}\right\}$ & $83,551,747$ & $27,850,5^{82}$ & 1912 & $30,646,163$ & I9Io & $24,898,345$ \\
\hline \multicolumn{7}{|c|}{ BeLgrum-Metric Tons. } \\
\hline 1100 & $\begin{array}{c}\text { Total } \\
\text { production }\end{array}$ & $\begin{array}{c}\text { Mean } \\
\text { annual } \\
\text { production }\end{array}$ & 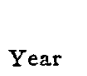 & Maximum & Yea & Minimum \\
\hline $\begin{array}{l}370 \\
779\end{array}$ & $I_{4} 6,893,125$ & $14,689,3$ I3 & 1873 & $\mathrm{I} 5,77^{8,40 \mathrm{I}}$ & I 877 & $13,669,077$ \\
\hline 380$\}$ & $179,771,122$ & $17,977,112$ & I889 & $19,869,980$ & I $88 \mathrm{I}$ & $16,873,951$ \\
\hline 890 & $206,800,233$ & $20,680,023$ & 1898 & $22, \mathrm{c}$ & I 893 & 19 \\
\hline 100 & $5^{87}$ & 59 & 1907 & o & 5 & 21, \\
\hline ro & $69,942,240$ & $23,314,060$ & 1910 & $23,916,560$ & 1912 & $22,972,140$ \\
\hline \multicolumn{7}{|c|}{ JAPAN-Metric Tons. } \\
\hline & $\begin{array}{l}\text { Total } \\
\text { production }\end{array}$ & ion & Year & Maximum & $\mathrm{Ye}$ & Minimum \\
\hline $8 \mathrm{I}$ & I $2,808,235$ & $I, 423,136$ & 1889 & & $188 \mathrm{I}$ & 925,198 \\
\hline $\left.\begin{array}{l}890 \\
899\end{array}\right\}$ & $45,721,857$ & $4,572,186$ & 1898 & 6,76 & 18 & $2,608,284$ \\
\hline $\left.\begin{array}{l}900 \\
909\end{array}\right\}$ & I I $5,283,197$ & $1,528,320$ & 1909 & $14,973,617$ & 1900 & $7,429,457$ \\
\hline $\left.\begin{array}{l}1910 \\
1912\end{array}\right\}$ & $52,953,789$ & $17,651,263$ & 1912 & I9,639,755 & & $\mathbf{I}$ \\
\hline
\end{tabular}

